\title{
Nucleic Acid Content in Male Fresh Water Fish N. notopterus Exposed to Copper Sulphate
}

\author{
K. Ravikiran*, R. S. Kulkarni \\ Fish Endocrinology Research Laboratory \\ Department of Post Graduate Studies and Research in Zoology \\ Gulbarga University Gulbarga - 585106 Karnataka, India \\ *E-mail address: ravikirankattimani@gmail.com
}

\begin{abstract}
The nucleic acid content in different tissues such as brain, liver, kidney $\&$ testis of both control and copper sulphate $\left(\mathrm{CuSO}_{4}\right)$ exposed freshwater fish $\mathrm{N}$. notopterus has been studied. The following observation is made in both control and copper sulphate $\left(\mathrm{CuSO}_{4}\right)$ exposed fish. The testis contain large amount of DNA in comparison to other tissues. The degree of DNA content in control and copper sulphate $\left(\mathrm{CuSO}_{4}\right)$ exposed fish testis $>$ liver $>$ brain $>$ kidney. The RNA content also exhibited similar to that of DNA, having higher amount in the testis. The degree of RNA content in control and copper sulphate (Cuso4) exposed fish testis $>$ liver $>$ brain $>$ kidney. The nucleic acid content of tissues get reduced under copper sulphate $\left(\mathrm{CuSO}_{4}\right)$ exposed in the male freshwater fish $\mathrm{N}$. notopterus indicating copper sulphate as a pollutant effect the nucleic acid content in the tissue.
\end{abstract}

Keywords: DNA; RNA; N. notopterus; $\mathrm{CuSO}_{4}$

\section{INTROUDCTION}

Water is an important natural resource essential for all living beings. The important water resources are ponds, lakes, rivers streams, etc. These water bodies provide water for drinking, irrigation, cooling industrial machines, and for other domestic purposes. So any harmful change in the water causes many ill-effects on the life of man and other animals. The undesirable change in water that has harmful affect on the life of man and domestic plants and animals is called water pollution. Urbanization due to population explosion and industrialization are the main causes for water pollution. Many organic and inorganic wastes from industries are discharged into water bodies. These wastes include heavy metals such as $\mathrm{Hg}, \mathrm{Cu}, \mathrm{Zn}$ lead etc., detergents, acids, alkalis, oils, phenols, petroleum, carbonates, alcohols, cyanides, arsenic, chlorine, etc.

Among several elements of the periodic table, there are 35 metals are associated with community and occupational exposure. Out of these, 23 are described as heavy metals. These elements are generally released in small amounts into the environment by processes like weathering of rocks, volcanic eruptions etc. and their intake/exposure is necessary in trace amounts for good health. But, presently, there is a steady increase in their concentration in all habitats owing to mining, electroplating, paints and dye, battery making industries etc. The release is rapid with the rapidly growing technology and heavy metal application in these 
industries. The two most important factors that contribute to the deleterious effects of heavy metals as pollutants are their indestructible nature through bioremediation unlike organic pollutants and their tendency to accumulate in environment especially in the bottom sediments of aquatic habitats in association with organic and inorganic matter. Out of the several heavy metals in the industrial waste streams (Forstner and Prosi, 1979).

Aquatic environments are loaded with several types of organic and inorganic pollutants. Huge amounts of agriculture pesticides, used for crop protection, eventually enter into the aquatic system. Similarly, heavy metals, which are released as industrial effluents form the major constituents of aquatic pollution. The presence of excess quantities of these toxic pollutants in water bodies has caused mass mortality of fishes in the past (Wanganeo et al., 1994).

The present study was undertaken on the freshwater fish $N$. notopterus keeping in view the above background. The study describes the toxicity levels of heavy metal like copper sulfate and their effects, of Copper sulphate found to be a pollutant causing deleterious effects on aquatic organisms at different levels, in the present study effects of copper sulphate on nucleic acid content of some important tissues of male freshwater fish $N$. notopterus has been undertaken.

\section{MATERIALS AND METHODS}

Fresh water fish $N$. notopterus (80-90 gm body weight) were brought from Bheema River around $40 \mathrm{kms}$ away from Gulbarga. Fish were acclimatized for laboratory condition for 7 days before the beginning of the experiment as where fish were fed during this adaptation period. This supplementary aeration provided optimum dissolved oxygen. Dissolved oxygen levels were recorded before experiment and after experiment. Water temperature was measured before and after the completion of experiment. Stable temperature of $27 \pm 3$ is an optimum temperature during the whole period of study. Fish were fed with earthworm and boiled egg pieces once daily from the day of arrival until the end of the experiment. This light provided for all aquaria during adoption and was about $12 \mathrm{hrs}$ of light: $12 \mathrm{hrs}$ of dark/day during the days of study.

\subsection{Use of Copper sulphate as a pollutant}

\subsubsection{Copper sulphate}

It is classified as general used material by environmental protection agency. Copper sulphate is a fungicide used to control bacterial and fungal diseases of fruit vegetable, nuts and field crops. Some of the diseases that are controlled by this fungicide include mildew, leaf spots, blights and apple scab. It is also used as an algaecide in irrigation and municipal water treatment system copper sulphate is an naturally occurring in-organic salt and copper is an essential trace element in plant and animal nutrition. It is available in dust wettable powders and fluid concentrates. 


\subsubsection{Physical properties}

It is blue in colour and odorless, it gives off moisture when exposed to air, copper sulphate $\left(\mathrm{CuSO}_{4}\right)$ in highly corrosive to plain steel, iron and galvanized. It is indefinitely stable when kept dry and is stable to heat, cold or light burning copper sulphate may produce irritating or poisonous gases and pollution may be caused by runoff from fire control or dilution water.

\subsubsection{Determination of $\mathrm{LC}_{50}$}

About 50 fishes from the stock were used for the determination of $\mathrm{LC}_{50}$. The fish were divided into 5 groups containing 10 fish in each Group, Group-I was kept as control and group II, III, IV, V were exposed in different concentration of 15 ppm, 20 ppm, 25 ppm, 30 ppm separately in Aquaria containing 25 liter of water. For a period of 96 hrs duration the experimental solution were changed every $24 \mathrm{hrs}$. The concentration that kills 50\%percent of the fish in $96 \mathrm{hrs}$ duration ( $\mathrm{LC}_{50} / 96 \mathrm{hrs}$ ) was determine by Static Bioassay method (Dandoroff et al., 1951) by using the mortality values for $96 \mathrm{hrs}$ the $\mathrm{LC}_{50}$ was determined by plotting the graph. The exposed fishes were sacrificed after $96 \mathrm{hrs}\left(\mathrm{LC}_{50}\right)$ and the tissues such as brain, liver, kidney and gonads were dissected out and processed for determination of the nucleic acid.

The nucleic acid (DNA and RNA) content of the tissue was estimated by Schneider (1940). In all the cases six observation were made and the results were expressed as arithmetic mean with their standard deviation, standard error and student " $\mathrm{t}$ " were made as described by Suedecur (1946) and Fisher (1963).

\section{RESULTS AND DISCUSSION}

After exposing fish, $N$. notopterus to different concentration of copper sulphate, the $\mathrm{LC}_{50}$ was found to be 25 ppm under this concentration (Table-1; Fig. 1) the fish were exposed for $96 \mathrm{hrs}$ and sacrificed. The nucleic acid (DNA/RNA) content in different tissues such as brain, liver, kidney and testis of both control and copper sulphate $\left(\mathrm{CuSO}_{4}\right)$ exposed male freshwater fish N. notopterus has been studied, during September month (i.e., spawning phase of the reproductive cycle).

The observation is made in both control and copper sulphate $\left(\mathrm{CuSO}_{4}\right)$ exposed fish. Amongst the four tissues, the testis contains larger amount of DNA in comparison to other tissues. The degree of DNA content in control and copper sulphate $\left(\mathrm{CuSO}_{4}\right)$ exposed fish although remains same, the DNA content reduces after $\mathrm{CuSO}_{4}$ exposure in all the tissues (testis $>$ liver $>$ brain $>$ kidney). The RNA content also exhibited similar to that of DNA. The degree of RNA content in control and copper sulphate $\left(\mathrm{CuSO}_{4}\right)$ exposed fish although remains same, the RNA content reduces after $\mathrm{CuSO}_{4}$ exposure (testis $>$ liver $>$ brain $>$ kidney) in all the tissues.

The DNA/RNA ratio's in different tissues found to be in a control unexposed fish is (Brain 2:1, Liver 2:1, Testis 2:1 and only in Kidney it is 1:1), and in Copper sulphate $\left(\mathrm{CuSO}_{4}\right)$ exposed although remains same, it is in the reduced condition (Brain has 2:1, Liver 2:1, Testis $2: 1$, and only in Kidney it is 1:1). (Table-2,Fig-2).

The level of DNA and RNA was found to be decreased in brain, liver, gonads, and kidney of $N$. notopterus fish due to exposure to copper sulphate indicating toxicity effects 
nucleic acid synthesis. The rapid histolysis in tissues because of copper sulphate treatment to fish is the only possible reason for this, alternation. Impairment of nucleic acid metabolism and the degradation of cells, resulting in the reduction of DNA content. Copper sulphate, inhibition of DNA changes, thus, might affect both protein as well as amino acid levels by decreasing the level of RNA in protein synthesis machinery. Copper sulphate as a potential inhibitor of DNA synthesis, might result in the reduction in the RNA level because of toxicity in nature many enzymes responsible for normal metabolic pathway are also affected.

RNA plays significant role in protein synthesis; depletion in RNA contents also results in depletion of protein levels. Hence, there is decrease in RNA level thus reducing protein synthesis. This is because of the animals requires more energy to overcome the stress upon exposure to the pollutant.

The DNA and RNA content of male fish tissues gets reduced under copper sulphate $\left(\mathrm{CuSO}_{4}\right)$ exposure in the freshwater fish $N$. notopterus indicating copper sulphate $\left(\mathrm{CuSO}_{4}\right)$ as a pollutant effects the reduction in the nucleic acid content in the tissues.

Environmental problems have always existed throughout human history but widespread recognition has come, understandably, one belatedly after many year of steadily accumulating pollution, pollution of environment by heavy metals is of prime importance unrestrained release of heavy metals into environment via discharge of industrial effluent sewage and agrochemicals into the water source has not only rendered in unusable but at the same time has produced great harm to fish (Vineetashukla et al., 2002).

The nucleic acid (DNA/RNA) content in different tissue of $N$. notopterus exposed to copper sulphate $\left(\mathrm{CuSO}_{4}\right)$ at $\mathrm{LC}_{50}$ concentration for $96 \mathrm{hrs}$ indicate that the DNA/RNA content of tissues reduced. Indicating copper sulphate as a pollutant effects the nucleic acid content in the tissues.

Adult pre-spawning fish Labeo rohita were sub lethally $\left(1 / 5^{\text {th }} 96 \mathrm{hrs} \mathrm{LC}_{50}\right)$ exposed to mercuric chloride and metacid-50 (methyl parathion). Accumulation of mercury and methyl parathion was studied and it was found that pre-spawning ovary appears as a potent organ for deposition of both the pollutants. RNA/DNA ratio of control and treated fish were studied. It was found that the significant decrease in RNA/DNA ratio occurs after 9 and 30 days of exposure for mercury and 30 days for methyl parathion. Fluorescence microscope studies by alcidine orange staining method were also performed to show how much is it related to biochemical alterations. In some cases loss of metachromasia is correlated with the fall in RNA/DNA ratio. Some other abnormalities like fall in stage II and I oocyte ratio and necrosis was also observed (Ajitkumar et al., 2002).

Accumulation of heavy metals and pesticide residues and their effect on fish physiology have been reported by several workers (Wilder and Stanley, 1989). Bhattacharya and Pandey (1989) reported Sonatox induced changes in the ovaries of Oreochromis mossambicus. Rajnarayan and Sathyanesan (1986) reported mercurial induced changes in the ovarian development of Channa punctatus. Sahai (1989) reported some histopathological changes in the ovaries of Puntius ticto by the treatment of several insecticides.

RNA/DNA ratio indicates the degree of metabolic (protein) synthesis. It is based on the fact that the DNA content per cell is constant within the same species, and the RNA is mainly ribosomic and varies with the rate of protein synthesis. It has been traditionally used as a growth index in ecological studies, in aquaculture and as a biomarker in long-term exposure experiments in ecotoxicology (Miliou et al., 1998). The sensitivity of the ratio as a biomarker has been questioned based on its lack of response in some experiments (Benton et al., 1994; Kim and Kang, 2004). In a recent study, Vidal et al. (2006) were able to associate RNA/DNA variations in $24 \mathrm{hrs}$ period and at different hours of the day in starved para larvae of the 
loliginid squid. The larval stages of cephalopods are very fast growing forms, metabolically very active. The sensitivity of the ratio is perhaps associated to the rate of metabolic activity and thus, early forms and fast-growing stages are more sensitive. For example, Barber et al. (1994) used successfully the ratio in $24 \mathrm{hrs}$ exposure of the crustacean Daphnia magna to cadmium, and Ibiam and Grant (2005) were also able to use the ratio as a sub lethal endpoint of copper exposure working with a nematode. In this sense, the fish used in the present study are still young fast-growing animals of only 80 days of age (Sellin et al., 2005).

The present study clearly indicates that a short term exposure of copper sulphate, the DNA \& RNA content of tissues get reduced in the freshwater fish $N$. notopterus indicating copper sulphate as a pollutant effect the nucleic acid content in the tissues.

Table 1. Showing $96 \mathrm{hrs}$ mortality rate of $N$. notopterus expressed as percentage exposed to copper sulphate toxicant.

\begin{tabular}{|c|c|c|c|c|}
\hline \multirow{2}{*}{$\begin{array}{c}\text { Aquarium } \\
\text { No. }\end{array}$} & $\begin{array}{c}\text { No. of test } \\
\text { animals } \\
\text { N. notopterus } \\
\text { fish }\end{array}$ & $\begin{array}{c}\text { Concentration of the } \\
\text { toxicant (Mg/L) }\end{array}$ & $\begin{array}{c}|c| \\
\text { No. of } \\
\text { fishes dead }\end{array}$ & $\begin{array}{c}\text { \%ours } \\
\text { Mortality }\end{array}$ \\
\hline 1. & 10 & Control (No toxicant) & Nil & Nil \\
\hline 2. & 10 & 15 & 1 & $10 \%$ \\
\hline 3. & 10 & 20 & 3 & $30 \%$ \\
\hline 4. & 10 & 25 & 5 & $50 \%$ \\
\hline 5. & 10 & 30 & 10 & $100 \%$ \\
\hline
\end{tabular}

Table 2. Showing DNA \& RNA content $(\mathrm{mg} / \mathrm{gm})$ in different tissues of the freshwater fish Notopterus notopterus on exposure to Copper sulphate $\left(\mathrm{CuSO}_{4}\right)$ MALE.

\begin{tabular}{|c|c|c|c|c|c|c|c|c|}
\hline \multirow{2}{*}{ Organs } & \multicolumn{2}{|c|}{ Brain } & \multicolumn{2}{c|}{ Liver } & \multicolumn{2}{c|}{ Kidney } & \multicolumn{2}{c|}{ Gonads } \\
\cline { 2 - 9 } & DNA & RNA & DNA & RNA & DNA & RNA & DNA & RNA \\
\hline \multirow{4}{*}{ Control } & $130 \pm$ & $45.62 \pm$ & $143 \pm$ & $49.33 \pm$ & $83.75 \pm$ & $47.16 \pm$ & 175.83 & $55 \pm$ \\
& 1.87 & 0.68 & 2.07 & 0.56 & 1.25 & 1.23 & \pm 1.63 & 1.00 \\
& $\mathrm{SE} \pm$ & $\mathrm{SE} \pm$ & $\mathrm{SE} \pm$ & $\mathrm{SE} \pm$ & $\mathrm{SE} \pm$ & $\mathrm{SE} \pm$ & $\mathrm{SE} \pm$ & $\mathrm{SE} \pm$ \\
& $0.7 \overline{6}$ & 0.27 & 0.84 & 0.22 & 0.51 & 0.50 & 0.66 & $0.4 \overline{6}$ \\
\hline \multirow{3}{*}{$\mathrm{CuSO}_{4}$} & 133.52 & $43.68+$ & $136.57 \pm$ & $45.50 \pm$ & $81.26+$ & $44.55+$ & $145 \pm$ & $53 \pm$ \\
exposed & $\pm 1^{\mathrm{NS}}$ & $1.25^{\mathrm{NS}}$ & $1.52^{* * *}$ & $1.60^{* *}$ & $1.26^{\mathrm{N}}$ & $0.63^{\mathrm{NS}}$ & $1.0^{* * *}$ & $1.50^{\mathrm{N} \mathrm{S}}$ \\
& $\mathrm{SE} \pm$ & $\mathrm{SE} \pm$ & $\mathrm{SE} \pm$ & $\mathrm{SE} \pm$ & $\mathrm{SE} \pm$ & $\mathrm{SE} \pm$ & $\mathrm{SE} \pm$ & $\mathrm{SE} \pm$ \\
& 0.50 & $0.5 \overline{0}$ & 0.60 & 0.50 & $0.7 \overline{8}$ & 0.50 & 0.50 & 0.50 \\
\hline
\end{tabular}

* Each value is expressed as Mean, Standard Deviation and Standard Error of six observations

Tukey method used:

$$
\begin{aligned}
& *=\mathrm{P}<0.05 \\
& * *=\mathrm{P}<0.01 \\
& * * *=\mathrm{P}<0.001 \\
& \mathrm{NS}=\text { No significant }
\end{aligned}
$$




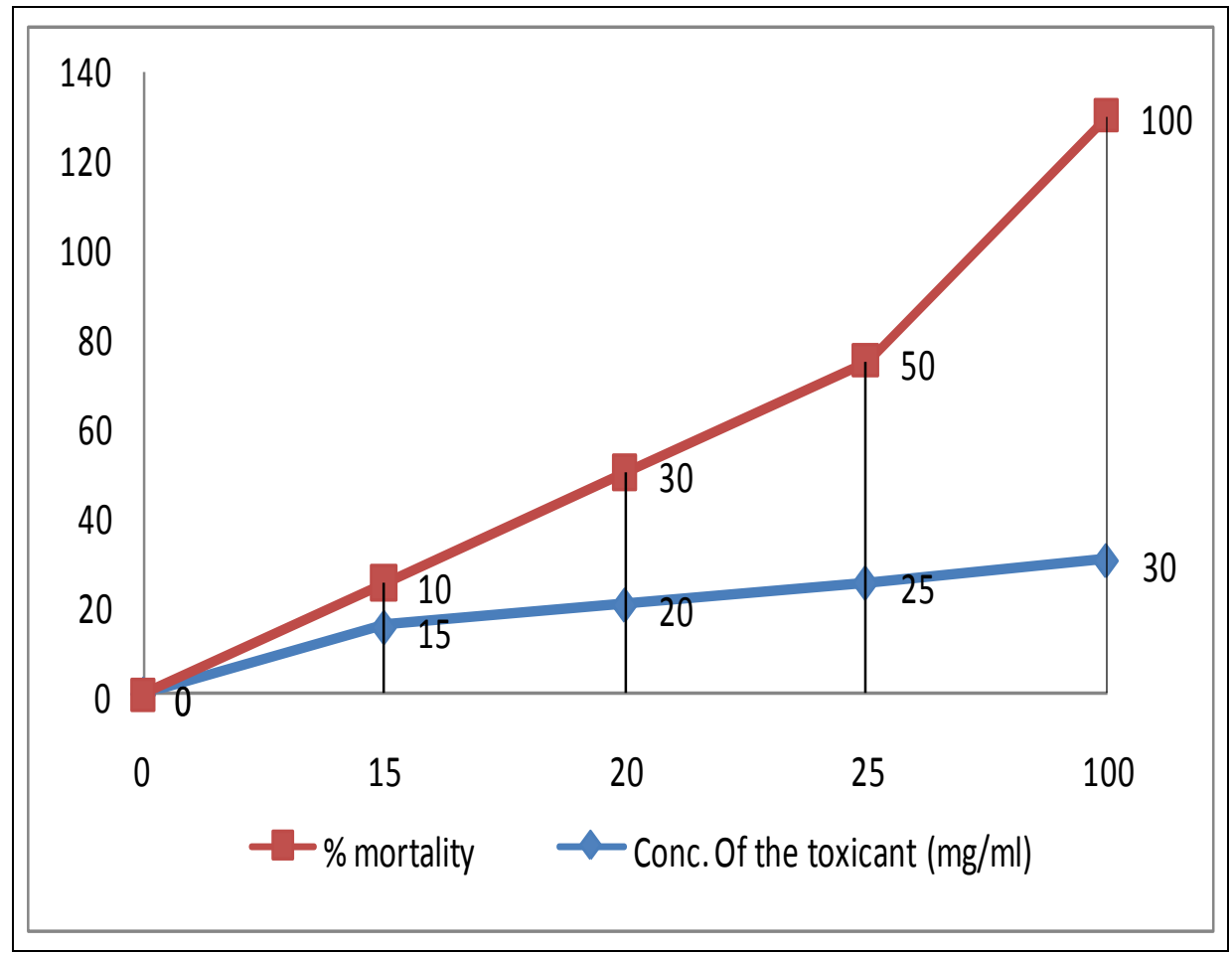

Fig. 1. Determination of $\mathrm{LC}_{50}$ by straight line graphical interpolation.

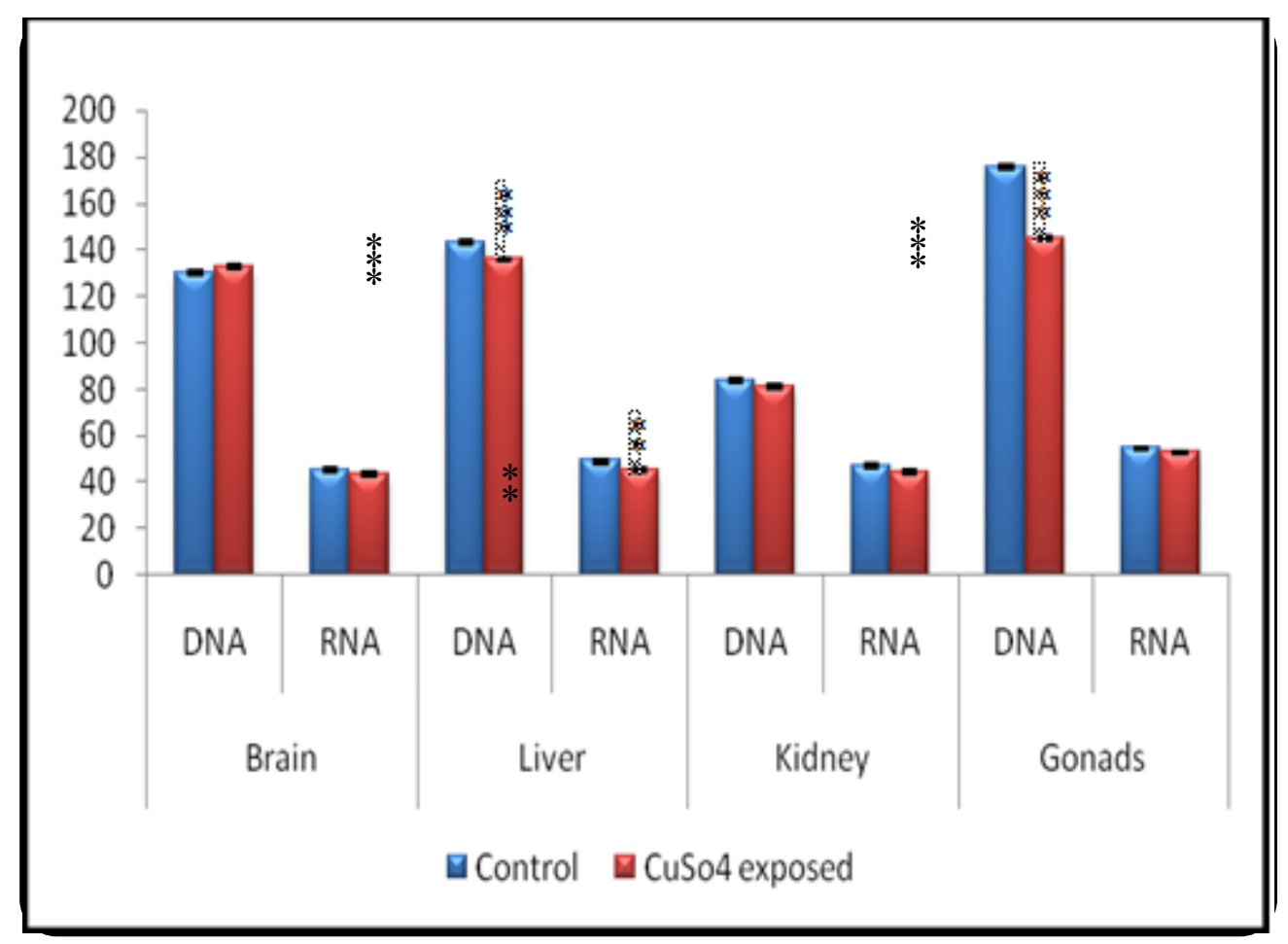

Fig. 2. Showing DNA \& RNA content $(\mathrm{mg} / \mathrm{gm})$ in different tissues of the freshwater male fish Notopterus notopterus on exposure to Copper sulphate $\left(\mathrm{CuSO}_{4}\right)$. 


\section{CONCLUSION}

The nucleic acid content in different tissues such as brain, liver, kidney \& testis of both control and copper sulphate $\left(\mathrm{CuSO}_{4}\right)$ exposed freshwater fish $\mathrm{N}$. notopterus has been studied. The following observation is made in both control and copper sulphate $\left(\mathrm{CuSO}_{4}\right)$ exposed fish. The testis contain large amount of DNA in comparison to other tissues. The degree of DNA content in control and copper sulphate $\left(\mathrm{CuSO}_{4}\right)$ exposed fish testis $>$ liver $>$ brain $>$ kidney. The RNA content also exhibited similar to that of DNA, having higher amount in the testis.

\section{References}

[1] Ajitkumar, Surabhi Vashistha and Parthasarathi (2002). Exposure to Interferon g Decreases Levels and Activity of Key Cell Cycle Proteins Resulting in Severe Growth Arrest of the Human Non-Transformed Cell Line, WISH. J. Cancer Sci. Ther., 3(1): 013019.

[2] Barber, W.E., Smith, R.L. and Weingartner, T.J. (1994). Fisheries oceanography of the northeast Chukchi Sea: final report. US Department of the Interior, Minerals Management Service, Anchorage, Alaska, OCS Study MMS-93-0051.

[3] Benton, E., Kloepper and Sams, P.J. (1994). Environ. Toxicol. Chem., 13:1483-1496.

[4] Bhattacharya, L. and Pandey, A.K. (1989). Sonatox induced impairment of ovarian activity in an exotic cichtid Oreochromis mossambicus (Linn). Foliamorphol (Progue), 37(1): 33-37.

[5] Doudoroff, P., Aderson, B.G., Burduck, G.E., Galtsaff, P.S., Hart, W.B., Pattrick, R., Stronge, E.R., Surber, E.W. and Van horn (1951). Bio-assay for the evaluation of acute toxicity of industrial wastes to fish. Sew. Ind. Wastes, 23: 1310-1397.

[6] Fisher, R. (1963). Statistical Methods for Research Worker Ed 6, Edinburgh.

[7] Forstner, U. and Prosi, F. (1979). Heavy metal pollution in freshwater systems. IN: Biological aspects of freshwater pollution (Ed. Ravera, O), Permagon Press, Oxford, pp. 129-159.

[8] Ibiam, U. and Grant, A. (2005). RNA/DNA ration as a sub lethal endpoint for large-scale toxicity with the nematode Caenorbditis elegans. Environ., Toxicol., Chem., 24:11551159.

[9] Kim, S., Kim, J. Kang (2004). Physiological and cellular responses in kidney of rockfish, Sebastes schlegli fed dietary cadmium. J. Fish. Sci. Tech.

[10]Miliou, H., Zaboukas, N. and Moraitou-Apostolopoulou, N. (1998). Biochemical composition, growth and survival of the Guppy, Poecilia reticulata, during chronic sublethal exposure to cadmium. Archives of Environmental Contamination and Toxicology, 35: 58-63.

[11]Rajnarayan, R. and Satyanesan, A.G. (1986). Effect of mercurial fungicide on the gonodal development of the teleostean fish, Channa punctalus (B1). Ecotoxical. Environ. Saf., 11: 352-355. 
[12] Sahai, S. (1989). Toxicology effect of some pesticides on ovaries of Puntitus ticto in, Trend in Environmental pollution and pesticides toxicology (Eds: Sashikant et al.). Today and Tomorrow, New Delhi, pp. 21-29.

[13]Sellin, M.K., Tate-Boldt, E. and Kolok, A.S. (2005). Acclimation to Cu in fathead minnows: Does age influence the response? Aquat. Toxicol., 74:97-109.

[14] Suedecur, C.W. (1946). Statistical methods low a state college press, Amesiowa.

[15] Vidal MA, Kilroy GE, Johnson JR, et al. 2006. Cell growth characteristics and differentiation frequency of adherent equine bone marrow-derived mesenchymal stromal cells: Adipogenic and osteogenic capacity. Vet Surg, 35:601-10.

[16] Vineetashukla, Pratima Rathi and Sastry, K.V. (2002). Effect of cadmium individually and in combination with other metals on the nutritive value of freshwater fish Channa punctatus, pp. 158-163.

[17] Wanganeo, A., S Pani, M.J.Nandan, and I.V.Suresh 1994. Incidence in fish mortality in lower lake of Bopal.Giobios, 21:145-146.

[18]Wilder, I.B. and Stanley, J.B. (1989). DNA- RNA ratios an index to growth to Salmonid fishes in laboratory and stream contaminated with carbaryl. J. Fish Biol., 22:165-172. 